\title{
Selection criteria for evaluating contractors of sgraffito technique in cultural heritage buildings
}

\author{
Žydrūnė Morkūnaitè \\ Department of Construction Management and Real Estate, \\ Vilnius Gediminas Technical University, Vilnius, Lithuania
}

\section{E-mail: zydrune.morkunaite@gmail.com}

\begin{abstract}
Sgraffito is a historical decorative technique applied in walls. This decoration could be seen in different European cities or villages. Nowadays, this decoration technique is almost disappeared because of decomposition, inexperience or lack of knowledge. Moreover, the preservation and restoration of sgrafitto technique is the most challenging and important task of cultural heritage buildings' preservation. Therefore, the preservation of sgraffito depends not only the historic and architectural knowledge, studies or conservation projects of the cultural heritage buildings, but also demands the experience, proper qualification and knowledge of contractor. This paper presents criteria set for selecting sgraffito techniques' contractor of heritage buildings. The study determines methods, set of criteria for sgraffito technique's contractor selection, overview of sets the assessment criteria of selecting contractor. The research applies the Analytic Hierarchy Process method (AHP), seeking to determine the critical criteria and to get the weighting for each criterion.
\end{abstract}

Keywords: sgraffito technique, cultural heritage, buildings, contractor, selection, AHP.

\section{Introduction}

Cultural heritage buildings are important source of community's memory, originality and attractiveness, reflecting buildings' historical, aesthetic, ethnic, religious value, and inducing cultural growth, economic development and social employment. One of the frequently visible techniques in cultural heritage buildings is sgraffito technique. This technique is a historical decorative technique applied in walls. Sgraffito was originated in Italy and later expanded in European cities and villages. However, nowadays this decoration technique is almost disappeared because of decomposition, inexperience or lack of knowledge. The preservation and restoration of sgrafitto technique is the most sophisticated task of cultural heritage buildings' preservation. Furthermore, sgraffito techniques' preservation and restoration depends not only on the historic and architectural knowledge, studies or conservation projects of the cultural heritage buildings, but also demands more of accountability and knowledge, thoroughness, and experienced employee. According to complex sgraffito technique, contractor selection for sgraffito conservation and restoration is not a simply task. Consequently, the inappropriate contractor selection could create disagreements, delays, claims, disputes and increased costs for project performance, organization and management. The success of construction and heritage project is strictly combined with construction project management (Ustinovičius, Shevchenko, Barvidas, Ashikhmin, \& Kochin, 2010) and proper contractor selection.

Nowadays, the most important criterion for tendering is price (Rajaprasad, 2018). However, the lowest price might not be the best solution to select a contractor. Accepting the lowest price tendering might be an essential cause of the project failure because very often the lowest price means poor quality, delays, claims, litigation, bankruptcy, contractor's capabilities such as poor planning of the resources and schedule, poor control of working flows.

Different criteria selection allows determining and evaluating the values of contractors. However, a specific criterion cannot give a complete definition of goals proposed by clients. The criteria selection is a complicated task which allows to evaluating contractor with respect to economic and technological aspects, quality standards, and organizational management, relationship with clients and stakeholders.

This paper presents criteria set for selecting sgraffito techniques' contractor of heritage buildings. The study determines methods, set of criteria for sgraffito technique's contractor selection, overview of sets the assessment criteria of selecting contractor. The research applies the Analytic Hierarchy Process method (AHP), seeking to determine the critical criteria and to get the weighting for each criterion. 


\section{Literature review}

\section{Contractor selection approaches}

The client for contractor selection applies diversified type of pre-selection procedures, like an open tendering, selective/restricted tendering, prequalification, negotiation (Nieto-Morote \& Ruz-Vila, 2012), the lowest bid or economically advantageous offer. Although, the low bid is one the most used methods for contractors' selection, some researchers proposed multi-criteria decision-making (MCDM) for miscellaneous contractor (Gao, 2018; Rajaprasad, 2018; Aboelmagd, 2018; Hasnain, Thaheem, \& Ullah, 2018) sub-contractor (Palha, de Almeida, \& Alencar, 2016; Ulubeyli \& Kazaz, 2016; Abbasianjahromi, Rajaie, \& Shakeri, 2013) and supplier (Yang, H. H. Wang, W. C. Wang, \& Ma, 2016; Polat, Eray, \& Bingol, 2017) selection.

Contractor selection, using AHP method integrated with other multi-criteria decision-making approaches, have been presented by many researchers. Rajaprasad (2018) developed an Integrated Model for contractors' selection, using combination of Analytic Hierarchy Process and Zero one integer linear programming. Aboelmagd (2018) selected the best contractor by AHP method integrated with Value Engineering (VE) technique. Assaf, Hassanain, Hadidi, and Amman (2017) presented AHP model for architects and engineering selection. Sarkis, Meade, and Presley (2012) applied AHP and ANP methods for sub-contractor selection. Nyongesa, Musumba, and Chileshe (2017) using Fuzzy AHP, suggested the partner selection. The subcontractor selection has presented by Polat (2016), applying the AHP and PROMETHEE methods. Subsequently, Polat et al. (2017) has selected supplier contractor by fuzzy AHP and fuzzy TOPSIS approaches. Plebankiewicz and Kubek (2016) proposed multi-criteria selection for the building material supplier, using AHP and Fuzzy AHP techniques. The contractor prequalification has been use by Nasab and Ghamsarian (2015), developing Fuzzy AHP and Fuzzy TOPSIS approaches. Hadidi and Khater (2015) proposed turnaround maintenance contractor selection, applying AHP method.

Additionally, Fuzzy Sets approaches were proposed for contractor or subcontractor selection. Keshavarz Ghorabaee, Amiri, Zavadskas, Turskis, and Antuchevičienė (2018) presented subcontractor evaluation, developing a dynamic Fuzzy approach based on EDAS technique. Contractor prequalification was proposed by Afshar, Alipouri, Sebt, and Chan (2017), developing a type-2 Fuzzy set. Alhumaidi (2015) used Fuzzy Set method for construction contractor selection. Nassar and Hosny (2013) estimated contractor performance, applying the Fuzzy-C method. Plebankiewicz (2012) has applied Fuzzy Sets approaches for contractor prequalification.

Moreover, contractor selection was proposed by the researchers, developing Fuzzy-ELECTRE and VIKOR (Hashemi, Mousavi, Zavadskas, Chalekaee, \& Turskis, 2018), ANP (Rashvand, Abd Majid, \& Pinto, 2015), WASPAS - G (Zavadskas, Turskis, \& Antuchevičienè, 2015), TOPSIS (San Cristobal, 2012), MOORA (Brauers, Zavadskas, Turskis, \& Vilutienè, 2008), COPRAS (Zavadskas, Kaklauskas, \& Vilutienė, 2009; Kaklauskas, Zavadskas, Raslanas, Ginevičius, Komkas, \& Malinauskas, 2006) approaches.

Nevertheless, contractor, subcontractor and supplier selection in construction field has been well analyzed in the literature, but contractor selection related to heritage projects has received less attention by researchers.

\section{Criteria considered}

The bidding for the most efficient contractor has played an essential role in the success of the construction projects. However, the lowest price still remains the dominant criterion in the most of procurement requirements. Most clients evaluate the tender by the lowest price, but this does not allow for clear and accurate evaluation of tender (Puri \& Tiwari, 2014). Moreover, the clients need that low price corresponding to the good value. Contractor selection based on lowest price is one of the major causes of the poor and unqualified performance (Banaitis \& Banaitienè, 2006). Therefore, the low bid procedure cannot ensure the selection of proper, conscientious and responsible contractor. In this case, the inappropriate contractor could induce enormous additional costs, poor quality of work, claims, disputes, litigation, abandonment of work, and bankruptcy.

Nowadays many researchers practice the shift from "lowest price wins" to "multi - criteria selection" method in contractor selection process. Numerous researchers have proposed the contractor selection criteria. The most common criteria studied by researchers during contractor evaluation and selection are financial strength (Gao, 2018; Rajaprasad, 2018; Zhang, Qi, \& Liang, 2018; Assaf, Hassanain, Hadidi, \& Amman, 2017; Polat, 2016; Liu, Huo, Liao, Gong, \& Xue, 2015; Nasab \& Ghamsarian, 2015; Attar, Khanzadi, Dabirian, \& Kalhor, 2013; Plebankiewicz, 2012), technical ability (Zhang, Qi, \& Liang, 2018; Ulubeyli \& Kazaz, 2016; Liu, Huo, Liao, Gong, \& Xue, 2015; Nasab \& Ghamsarian, 2015; Zavadskas, Turskis, \& Antuchevičienė, 2015; Attar, Khanzadi, Dabirian, \& Kalhor, 2013; Hartmann \& Caerteling, 2010), management capacity (Yang, H. H. Wang, W. C. Wang, \& Ma, 2016; Kog \& Yaman, 2016; Hadidi \& Khater, 2015; Zavadskas, Turskis, \& Antuchevičienè, 2015; Egemen \& Mohamed, 2006), previous performance (Hasnain, Thaheem, \& Ullah, 2018; Afshar, Alipouri, Sebt, \& Chan, 2017; Keung \& Yiu, 2015; Nieto-Morote \& Ruz-Vila, 2012), experience (Aboelmagd, 2018; Assaf, Hassanain, Hadidi, \& Amman, 2017; Yang, H. H. Wang, W. C. Wang, \& Ma, 2016; Keung \& Yiu, 2015; Egeme \& Mohamed, 2006), reputation (Assaf, Hassanain, Hadidi, \& Amman, 2017; Kog \& Yaman, 2016; Keung \& Yiu, 2015), and health and safety (Gao, 2018; Hasnain, Thaheem, \& Ullah, 2018; Hadidi \& Khater, 2015; Zavadskas, Turskis, \& Antuchevičienė, 2015; Liu, Huo, Liao, Gong, \& Xue, 2015; Attar, Khanzadi, Dabirian, \& Kalhor, 2013). Moreover along with these main criteria was 
determined also criteria, follow as bid price (Nguyen, 2018; Polat, 2016; Palha, de Almeida, \& Alencar, 2016; Abbasianjahromi, Rajaie, \& Shakeri, 2013; Hartmann \& Caerteling, 2010), personnel (Afshar, Alipouri, Sebt, \& Chan, 2017; Polat, 2016; Hadidi \& Khater, 2015; Gosling, Purvis, \& Naim, 2010), quality (Nguyen, 2018; Aboelmagd, 2018; Nasab \& Ghamsarian, 2015), resources (physical, human) (Fong \& Choi, 2000; Cheng \& Li, 2004), time (Palha, de Almeida, \& Alencar, 2016; Abbasianjahromi, Rajaie, \& Shakeri, 2013; Plebankiewicz, 2012; Zavadskas, Turskis, \& Tamošaitienè, 2008; Banaitis \& Banaitienė, 2006, Chinyio, Olomolaiye, Kometa, \& Harris, 1998; Holt, 1998), risk (Palha, de Almeida, \& Alencar, 2016; Turskis, 2008; Banaitis \& Banaitienè, 2006), and past relantiosnhip (Ulubeyli \& Kazaz, 2016; Nieto-Morote \& Ruz-Vila, 2012; Gosling, Purvis, \& Naim, 2010).

Several researchers (Hasnain, Thaheem, \& Ullah, 2018; Zhang, Qi, \& Liang, 2018; Assaf, Hassanain, Hadidi, \& Amman, 2017; Kog \& Yaman, 2016; Polat, 2016; Nasab \& Ghamsarian, 2015; Abbasianjahromi, Rajaie, \& Shakeri, 2013; Attar, Khanzadi, Dabirian, \& Kalhor, 2013; Nieto-Morote \& Ruz-Vila, 2012; Nassar \& Hosny, 2013; Hartmann $\mid \&$ Caerteling, 2010; Sarkis, Meade, \& Presley, 2012) determined contractor selection sub-criteria, which has grouped into principal criteria.

Additionally, Nassar and Hosny (2013) proposed quantitative and qualitative measures, evaluating contractor. Quantitative measures consist of schedule, cost and safety performance measure and determined combined score. Qualitative measures include staff and equipment quality, safety and environment protection, quality and other factors. Hassim, Muniandy, Alias, and Abdullah (2018) presented criteria for construction tender price estimation, follow as complexity of design and construction, acceptable production time, market condition, and clients' financial situation. Keshavarz Ghorabaee, Amiri, Zavadskas, Turskis, and Antuchevičienė (2018) proposed reliability, schedule-control and management ability, and labor quality criteria. Juan (2009) evaluated housing refurbishment contractors, using schedule and budget change, quality defect, experience, conflicts and complaints and tangibles, empathy, reliability, responsiveness, assurance satisfaction criteria. Zavadskas and Vilutiene (2006), Brauers et al. (2008), Zavadskas et al. (2009) evaluated maintenance contractor by criteria describe such as cost of building, common property management, HVAC system maintenance and total service, number of maintained buildings, income from common property maintenance per employee. However, Zavadskas and Vilutienè (2006), Zavadskas, Kaklauskas and Vilutienè (2009) as well as have used qualitative criteria for maintenance contractor selection. These criteria consist of length of time, market share, number of projects, management cost, work organization and etc.

Although, the researchers have studied and proposed different criteria for contractor selection, however these criteria are generic and not include the particular criteria relating with sgraffito technique and heritage buildings' projects. Selecting contractor for cultural heritage buildings conservation and restoration applies the heritage and construction legislation. Consequently, this study proposes criteria and sub-criteria, which are combined with heritage and construction field and based on the author accomplished criteria's analyse.

\section{Determining the evaluation criteria of the contractor section for sgraffito technique of cultural heritage buildings}

Studies have showed that for the best economic results and good quality, the lowest price tendering is not considered sufficient to assure the desired results. Within the focus of the outcome of any construction activity is the realization of minimal cost, timely delivery and quality-oriented structure, not an exception and cultural heritage projects, particularly, sgraffito technique and its preservation and restoration. In this case, this type of performance is more complex. The contractors have to have an experience in heritage field, knowledge of sgraffito technique, qualified employees, know the legislation. Therefore, the selection of suitable contractor for heritage project is a very complex task for clients in the construction industry.

The contractor plays an important role in project success, and consequently the contractor selection is a responsible and crucial decision making process. The present paper determines six principal criteria and sub-criteria (Figure 1) of contractor selection for sgraffito technique of cultural heritage buildings.

The main criteria are financial strength $\left(\mathrm{x}_{1}\right)$, contracts' value $\left(\mathrm{x}_{2}\right)$, sub-contractor $\left(\mathrm{x}_{3}\right)$, management capability $\left(\mathrm{x}_{4}\right)$, risk $\left(\mathrm{x}_{5}\right)$, and reputation $\left(\mathrm{x}_{6}\right)$. Financial strength is presented by sub-criteria such as income $\left(\mathrm{x}_{11}\right)$, days sales $\left(\mathrm{x}_{12}\right)$ and payable $\left(\mathrm{x}_{13}\right)$ outstanding. These sub-criteria show the contractor ability to manage and organize the finances of his company. Contracts' value demonstrates the contractor capability to award the public procurement in cultural heritage field. This criterion consists of sub-criteria, such as value of total contracts $\left(\mathrm{x}_{21}\right)$, performed heritage work's value $\left(\mathrm{x}_{22}\right)$ (not less than 100 thousand euro) and number of total contracts $\left(\mathrm{x}_{23}\right)$. Sub-contractor criterion demonstrates the total number of procurements, where the main contractor have been attended and rewarded together with sub-contractors in cultural heritage buildings field. Management capability criterion presents contractor organizations' skill according to the qualified and experienced employees. The criterion consist of certification for special buildings' material ( $\left.\mathrm{x}_{41}\right)$, total number of employee $\left(\mathrm{x}_{42}\right)$ and not less than one or two qualified specialist for stone and brick masonry ( $\left.\mathrm{x}_{43}\right)$, and for decorative plaster and coatings works $\left(\mathrm{x}_{44}\right)$. The risk criterion indicates the riskiness of the companies. Reputation presents clients' and stakeholders' complaints and reviews. Furthermore, all author's proposed criteria, firstly, are related with cultural heritage field and, subsequently, with construction field. 


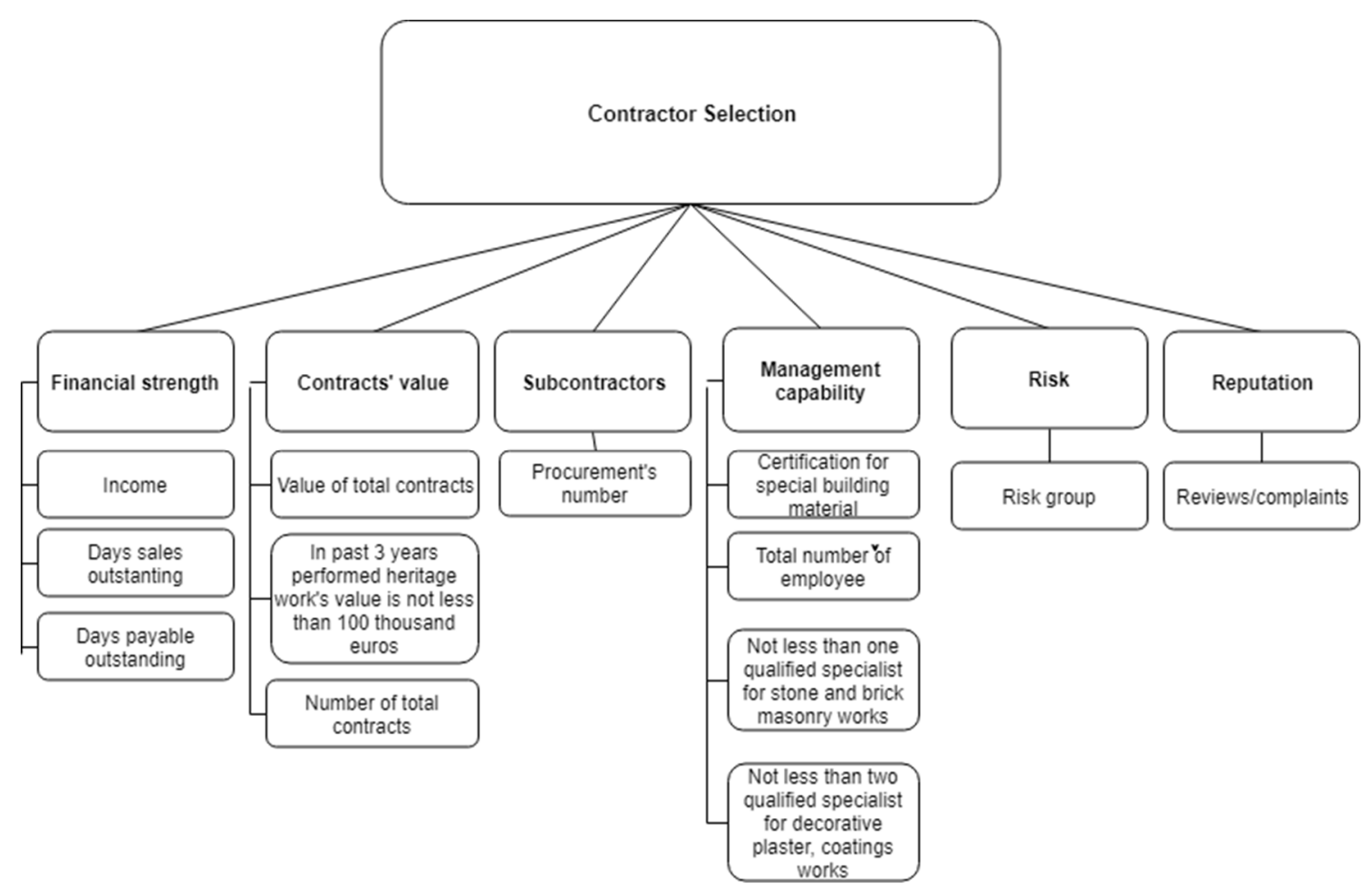

Figure 1. Criteria and subcriteria applied in heritage contractor selection for sgraffito technique of cultural heritage buildings

The author of the article decided to determine the weights (significances) of criteria for sgraffito technique of cultural heritage buildings, using AHP method.

For this case of study, ten experts from the local government, academics and professionals or experts in sgraffito technique and heritage buildings were invited to form an evaluation panel and judge the weighting of evaluation items.

\section{The application of AHP method}

The AHP method, broadly used multi criteria decision making, was suggested by Saaty (1980). This approach is based on pairwise comparisons of criteria. AHP method demands decision-makers to supply judgments about the comparative significance of each criterion. For this reason, it helps to prioritize the selection criteria and to identify the crucial criteria from less crucial ones (Kutut, Zavadskas, \& Lazauskas, 2014). Moreover, AHP approach allows determine the weights (significances) of particular hierarchical level.

Saaty (1980) proposed a nine- level dominance scale (Table 1) and Random Consistency Indices (IR) for a number of various criteria $(n)$ (Table 2). Pairwise comparison (Table 3 ) is based on the weighting principle, when one criterion is more significant than the other.

Table 1. The Saaty Rating Scale

\begin{tabular}{|c|c|c|c|c|c|c|c|}
\hline & $\begin{array}{c}C_{i} \text { and } C_{j} \\
\text { are equal } \\
\text { importance }\end{array}$ & $\begin{array}{c}C_{i} \text { is weakly } \\
\text { more } \\
\text { important } \\
\text { than } C_{j}\end{array}$ & $\begin{array}{c}C_{i} \text { is much } \\
\text { more } \\
\text { important } \\
\text { than } C_{j}\end{array}$ & $\begin{array}{c}C_{i} \text { is very } \\
\text { much more } \\
\text { important } \\
\text { than } C_{j}\end{array}$ & $\begin{array}{c}C_{i} \text { is } \\
\text { absolutely } \\
\text { more important } \\
\text { than } C_{j}\end{array}$ & $\begin{array}{c}\text { Compromise } \\
\text { between two } \\
\text { judgments/interme } \\
\text { diate values }\end{array}$ & $\begin{array}{c}\text { If element } C_{j} \\
\text { dominates } \\
\text { element } C_{i}\end{array}$ \\
\hline$a_{i j}$ & 1 & 3 & 5 & 7 & 9 & $2,4,6,8$ & $a_{i j}=1 / a_{i j}$ \\
\hline
\end{tabular}

Table 2. Random Consistency Indices $(I R)$ for a number of various criteria $(n)$

\begin{tabular}{|c|c|c|c|c|c|c|c|c|c|c|c|c|c|}
\hline$n$ & 3 & 4 & 5 & 6 & 7 & 8 & 9 & 10 & 11 & 12 & 13 & 14 & 15 \\
\hline$R I$ & 0.58 & 0.90 & 1.12 & 1.24 & 1.32 & 1.41 & 1.45 & 1.49 & 1.51 & 1.48 & 1.56 & 1.57 & 1.59 \\
\hline
\end{tabular}


Table 3. Criteria pairwise comparison matrix

\begin{tabular}{|l|c|c|c|c|c|c|}
\hline & $\begin{array}{c}\text { Financial } \\
\text { strength }\end{array}$ & $\begin{array}{c}\text { Contracts' } \\
\text { value }\end{array}$ & $\begin{array}{c}\text { Sub- } \\
\text { contractors }\end{array}$ & $\begin{array}{c}\text { Management } \\
\text { capability }\end{array}$ & Risk & Reputation \\
\hline Financial strength & 1.00 & 0.50 & 7.00 & 6.00 & 4.00 & 3.00 \\
\hline Contracts' value & 2.00 & 1.00 & 9.00 & 7.00 & 5.00 & 4.00 \\
\hline Sub-contractors & 0.14 & 0.11 & 1.00 & 0.33 & 0.25 & 0.17 \\
\hline Management capability & 0.17 & 0.14 & 3.00 & 1.00 & 0.33 & 0.20 \\
\hline Risk & 0.25 & 0.20 & 4.00 & 3.00 & 1.00 & 0.33 \\
\hline Reputation & 0.33 & 0.25 & 6.00 & 5.00 & 3.00 & 1.00 \\
\hline
\end{tabular}

The process of AHP approach for is described in four general steps: (1) creating a decision problem, (2) developing of pairwise comparison matrix, (3) verifying the consistency ratio, (4) conclusion of priorities for the criteria (Song, 2019).

\section{The AHP approach is a stepwise process:}

Step 1. When the judgements have finished pairwise comparison of criteria, the results are presented in the pairwise comparison matrix. Experts compare all the evaluation criteria $C i$ and $C j(i, j=1,2, \cdots, n)$, where $n$ is the number of the criteria compared.

$$
A=\left[c_{i j}\right]=\begin{gathered}
C_{1} \\
C_{2} \\
\vdots \\
C_{n}
\end{gathered}\left[\begin{array}{cccc}
1 & a_{12} & \cdots & a_{1 n} \\
1 / a_{12} & 1 & \cdots & a_{2 n} \\
\vdots & \vdots & \ddots & \vdots \\
1 / a_{1 n} & 1 / a_{2 n} & \cdots & 1
\end{array}\right] .
$$

Step 2. Normalize the pairwise comparison matrix as follows:

$$
\bar{A}=\left[\bar{c}_{i j}\right]=\frac{c_{i j}}{\sum_{j=1}^{n} c_{n j}} .
$$

Step 3. Calculate the criteria weights:

$$
W=\left[\begin{array}{c}
w_{1} \\
w_{2} \\
\vdots \\
w_{n}
\end{array}\right]=\frac{\sum_{j=1}^{n} \bar{c}_{i j}}{n}
$$

Step 4. Determine the largest eigenvalue:

$$
\lambda_{\text {max }}=\sum_{j=1}^{n} c_{i j} w_{i j} .
$$

Step 5. Determine the Consistency Index $(C I)$ :

$$
C I=\frac{\lambda_{\max }-1}{n-1} .
$$

Step 6. Determine the Consistency Ratio $(C R)$ :

$$
C R=\frac{C I}{R I},
$$

where $R I$ presents the average consistency index over numerous random elements of the same order reciprocal matrices.

Step 7. Assure that the pairwise comparison matrix is consistent. The Consistency Ratio (CR) is below 0.1 , the consistency of the judgments' matrix is considered reasonable. Otherwise, is obligated to go to the first step. 
Table 4 presents the results of calculating criteria weights.

Table 4. Calculated weights of criteria

\begin{tabular}{|c|c|c|c|c|c|c|}
\hline & Financial strength & Contractor's value & Subcontractors & Management capability & Risk & Reputation \\
\hline Weight & 0.271 & 0.401 & 0.029 & 0.050 & 0.089 & 0.160 \\
\hline
\end{tabular}

For this study, the Consistency Ratio coefficient is calculated by descripted AHP approach process follows as:

1. $\chi_{\max }=6.521$;

2. $\mathrm{CI}=0.104$

3. $\mathrm{RI}=1.240$;

4. $\mathrm{CR}=0.084$.

The Consistency Ratio (CR) does not exceed the condition $\mathrm{CR}<0.1$. For this reason, the matrix is consistent and the judgements' estimates are in agreement.

The agreements of experts and determined results show that the important criteria for contractor selection are contractor's value $(0.401)$ and financial $(0.271)$ strength. Contractor's value criterion demonstrates the contractor ability of rewarding the public procurement in cultural heritage field, managing performance and employees relevant with culture heritage buildings. Meanwhile, the financial strength criterion presents the contractor capability related with contractor financial management and organization. Nevertheless, the less important criterion is subcontractors, which demonstrates not importance of the total number of procurements, where the main contractor have been attended and rewarded together with sub-contractors in cultural heritage buildings field. According to the cultural heritage contractor selection for sgraffito technique process and determined results, the most consideration has to be taken into the contractors' value and financial strength.

\section{Conclusions}

Sgraffito technique is very complex technique, which has been used in Europe since Renaissance and discoverable till nowadays. Therefore, seeking to properly preserve and restore this technique, is not enough to appreciate the historic and architectural knowledge, to know conservation projects of the cultural heritage buildings, but also demands the experience, proper qualification and knowledge of contractor. The improper contractor selection for sgraffito technique preservation and conservation could damage historical, architectural, artistic heritage value, create disagreements, delays, claims, disputes and increased costs for project performance, organization and management. The appropriate criteria selection and determination allows selecting qualified, responsible and conscientious contractor. This study presents determining the weights of criteria for selecting the appropriate contractor for sgraffito technique preservation and restoration of cultural heritage buildings. The author has determined a set of criteria providing to evaluate a suitable heritages' contractor for sgraffito technique of cultural heritage buildings. These criteria include financial strength, contracts' value, subcontractor, management capability, risk and reputation issues.

Author has proposed applying AHP method for problem solution. According to judgments of experts, applied technique and calculated results, the important criteria for contractor selection are contractor's value and financial strength. Contractors' value criterion shows contractor's experience, qualify and approach to the work. Furthermore, this criterion demonstrates the contractor ability of rewarding the public procurement in cultural heritage field, managing performance and employees relevant with culture heritage buildings. Meanwhile, the financial strength shows the contractor capability related with contractor financial management and evaluate enterprise's income or profit, days that enterprise takes to evaluate and collect their incomes after a performance has been made and days that enterprise moderate payable period, which estimates how long takes an enterprise have to pay its invoices from suppliers or sub-contractors. Nevertheless, the less important criterion is subcontractors, which demonstrates not importance of the total number of procurements, where the main contractor have been attended and rewarded together with sub-contractors in cultural heritage buildings field.

The proposed method is based on objective or subjective considerations, which play a crucial role during the decision process. AHP is related on the judgments of experts from diverse experiences, for this reason the main problem can be evaluated easily from various aspects. However, the limitations for the use of the presented approach are accurate qualities for experts, such as the human emotions and experts may not understand pairwise comparison of criteria. Consequently, this means that method cannot guarantee the agreements as clearly true. Further suggestions for research are proposed applying both subjective and objective approaches for precise criteria evaluation and their weights. 


\section{References}

Abbasianjahromi, H., Rajaie, H., \& Shakeri, E. (2013). A framework for subcontractor selection in the construction industry. Journal of Civil Engineering and Management, 19(2), 158-168. https://doi.org/10.3846/13923730.2012.743922

Aboelmagd, Y. M. R. (2018). Decision support system for selecting optimal construction bid price. Alexandria Engineering Journal, 57(4), 4189-4205. https://doi.org/10.1016/j.aej.2018.11.007

Afshar, M. R., Alipouri, Y., Sebt, M. H., \& Chan, W. T. (2017). A type-2 fuzzy set model for contractor prequalification. Automation in Construction, 84, 356-366. https://doi.org/10.1016/j.autcon.2017.10.003

Alhumaidi, H. M. (2015). Construction contractors ranking method using multiple decision-makers and multiattribute fuzzy weighted average. Journal of Construction Engineering and Management, 141(4). https://doi.org/10.1061/(ASCE)CO.1943-7862.0000949

Assaf, S., Hassanain, M. A., Hadidi, L., \& Amman, A. (2017). A systematic approach for the selection of the architect/engineer professional in construction projects. Architecture Civil Engineering Environment, 10(4), 5-14. https://doi.org/10.21307/acee-2017-047

Attar, M. M., Khanzadi, M., Dabirian, M., \& Kalhor, E. (2013). Forecasting contractor's deviation from the client objectives in prequalification model using support vector regression. International Journal of Project Management, 31(6), 924-936. https://doi.org/10.1016/j.ijproman.2012.11.002

Banaitis, A., \& Banaitienè, N. (2006). Analysis of criteria for contractors' qualification evaluation. Technological and Economic Development of Economy, 12(4), 276-282. https://doi.org/10.3846/13928619.2006.9637754

Brauers, W. K. M., Zavadskas, E. K., Turskis, Z., \& Vilutienė, T. (2008). Multi-objective contractor's ranking by applying MOORA method. Journal of Business Economics and Management, 9(4), 245-255. https://doi.org/10.3846/1611-1699.2008.9.245-255

Cheng, E. W. L., \& Li, H. (2004). Contractor selection using the analytic network process. Construction Management and Economics, 22, 1021-1032. https://doi.org/10.1080/0144619042000202852

Chinyio, E. A., Olomolaiye, P. O., Kometa, S. T., \& Harris, F. C. (1998). A needs - based methodology for classifying construction clients and selecting contractors. Construction Management and Economics, 16, 91-98. https://doi.org/10.1080/014461998372628

Egemen, M., \& Mohamed, A. N. (2006). Clients' needs, wants and expectations from contractors and approach to the concept of repetitive works in the Northern Cyprus construction market. Building and Environment, 41(5), 602-614. https://doi.org/10.1016/j.buildenv.2005.02.021

Fong, S. P., \& Choi, S. K. (2000). Final contractor selection using the analytic hierarchy process. Construction Management and Economics, 18, 547-557. https://doi.org/10.1080/014461900407356

Gao, G. X. (2018). Sustainable winner determination for public-private partnership infrastructure projects in multi-attribute reverse auctions. Sustainability, 10(11), 4129. https://doi.org/10.3390/su10114129

Gosling, J., Purvis, L., \& Naim, M. M. (2010). Supply chain flexibility as a determinant of supplier selection. International Journal of Production Economics, 128(1), 11-21. https://doi.org/10.1016/j.ijpe.2009.08.029

Hadidi, L. A., \& Khater, M. A. (2015). Loss prevention in turnaround maintenance projects by selecting contractors based on safety criteria using the analytic hierarchy process (AHP). Journal of Loss Prevention in the Process Industries, 34, 115123. https://doi.org/10.1016/j.jlp.2015.01.028

Hartmann, A., \& Caerteling, J. (2010). Subcontractor procurement in construction: the interplay of price and trust. Supply Chain Management - an International Journal, 15(5), 354-362. https://doi.org/10.1108/13598541011068288

Hashemi, H., Mousavi, S. M., Zavadskas, E. K., Chalekaee, A., \& Turskis, Z. (2018). A new group decision model based on greyintuitionistic Fuzzy-ELECTRE and VIKOR for contractor assessment problem. Sustainability, 10(5), 1635. https://doi.org/10.3390/su10051635

Hasnain, M., Thaheem, M. J., \& Ullah, F. (2018). Best value contractor selection in road construction projects: ANP-based decision support system. International Journal of Civil Engineering, 16(6), 695-714. https://doi.org/10.1007/s40999-017-0199-2

Hassim, S., Muniandy, R., Alias, A. H., \& Abdullah, P. (2018). Construction tender price estimation standardization (TPES) in Malaysia: modeling using fuzzy neural network. Engineering Construction and Architectural Management, 25(3), 443-457. https://doi.org/10.1108/ECAM-09-2016-0215

Holt, G. D. (1998). Which contractor selection methodology? International Journal of Project Management, 16(3), 153-164. https://doi.org/10.1016/S0263-7863(97)00035-5

Juan, Y. K. (2009). A hybrid approach using data envelopment analysis and case-based reasoning for housing refurbishment contractors' selection and performance improvement. Expert System with Applications, 36(3), 5702-5710. https://doi.org/10.1016/j.eswa.2008.06.053

Kaklauskas, A., Zavadskas, E. K., Raslanas, S., Ginevičius, R., Komka, A., \& Malinauskas, P. (2006). Selection of low-e windows in retrofit of public buildings by applying multiple criteria method COPRAS: a Lithuanian case. Energy and Buildings, 38(5), 454-462. https://doi.org/10.1016/j.enbuild.2005.08.005

Keshavarz Ghorabaee, M., Amiri, M., Zavadskas, E. K., Turskis, Z., \& Antuchevičienė, J. (2018). A dynamic Fuzzy approach based on the EDAS method for multi criteria subcontractor evaluation. Information, 9(68), 1-15. https://doi.org/ 0.3390/info9030068

Keung, C. W., \& Yiu, T. W. (2015). Potential for long-term sustainability A visit of bidding objectives and strategies from maintenance contractor's perspective. Facilities, 33(3-4), 177-195. https://doi.org/10.1108/F-07-2013-0056 
Kog, F., \& Yaman, H. (2016). A multi-agent systems-based contractor pre-qualification mode. Engineering Construction and Architectural Management, 23(6), 709-726. https://doi.org/10.1108/ECAM-01-2016-0013

Kutut, V., Zavadskas, E. K. \& Lazauskas, M. (2014). Assessment of priority alternatives for preservation of historic buildings using model based on ARAS and AHP methods. Archives of Civil and Mechanical Engineering, 14, 287-294. https://doi.org/10.1016/j.acme.2013.10.007

Liu, B. S., Huo, T. F., Liao, P. C., Gong, J., \& Xue, B. (2015). A group decision-making aggregation model for contractor selection in large scale construction projects based on two-stage Partial Least Squares (PLS) path modeling. Group Decision and Negotiation, 24(5), 855-883. https://doi.org/10.1007/s10726-014-9418-2

Nasab, H. H., \& Ghamsarian, M. M. (2015). A fuzzy multiple-criteria decision-making model for contractor prequalification. Journal of Decision Systems, 24(4), 433-448. https://doi.org/10.1080/12460125.2015.1081048

Nassar, K., \& Hosny, O. (2013). Fuzzy clustering validity for contractor performance evaluation: application to UAE contractors. Automation in Construction, 31, 158-168. https://doi.org/10.1016/j.autcon.2012.11.013

Nguyen, P. T. (2018). Determination of construction supplier evaluation criteria using word tags. International Journal of Advanced and Applied Sciences, 5(11), 75-79. https://doi.org/10.21833/ijaas.2018.11.010

Nieto-Morote, A., \& Ruz-Vila, F. (2012). A fuzzy multi-criteria decision-making model for construction contractor prequalification. Automation in Construction, 25, 8-19. https://doi.org/10.1016/j.autcon.2012.04.004

Nyongesa, H. O., Musumba, G. W., \& Chileshe, N. (2017). Partner selection and performance evaluation framework for a construction-related virtual enterprise: a multi-agent systems approach. Architectural Engineering and Design Management, 13(5), 344-364. https://doi.org/10.1080/17452007.2017.1324398

Palha, R. P., de Almeida, A. T., \& Alencar, A. H. (2016). A model for sorting activities to be outsourced in civil construction based on ROR-UTADIS. Mathematical Problems in Engineering, Article ID 9236414, 15. https://doi.org/10.1155/2016/9236414

Plebankiewicz, E. (2012). A fuzzy sets based contractor prequalification procedure. Automation in Construction, 22, 433-443. https://doi.org/10.1016/j.autcon.2011.11.003

Plebankiewicz, E., \& Kubek, D. (2016). Multicriteria selection of the building material supplier using AHP and Fuzzy AHP. Journal of Construction Engineering and Management, 142(1). https://doi.org/10.1061/(ASCE)CO.1943-7862.0001033

Polat, G. (2016). Subcontractor selection using the integration of the AHP and PROMETHEE methods. Journal of Civil Engineering and Management, 22(8), 1042-1054. https://doi.org/10.3846/13923730.2014.948910

Podvezko, V. (2009). Application of AHP technique. Journal of Business Economics and Management, 10(2), 181-189. https://doi.org/10.3846/1611-1699.2009.10.181-189

Polat, G., Eray, E., \& Bingol, B. N. (2017). An integrated fuzzy MCGDM approach for supplier selection problems. Journal of Civil Engineering and Management, 23(7), 926-942. https://doi.org/10.3846/13923730.2017.1343201

Puri, D., \& Tiwari, S. (2014). Evaluating the criteria for contractors' selection and bid evaluation. International Journal of Engineering Science Invention, 3(7), 44-48.

Rajaprasad, S. V. S. (2018). Selection of contractors for a housing development project in India by using integrated model. International Journal of Sustainable Construction Engineering and Technology, 9(1), 58-68. https://doi.org/10.30880/ijscet.2018.09.01.005

Rashvand, P., Abd Majid, M. Z., \& Pinto, J. K. (2015). Contractor management performance evaluation model at prequalification stage. Expert System with Applications, 42(12), 5087-5101. https://doi.org/10.1016/j.eswa.2015.02.043

San Cristobal, J. R. (2012). Contractor selection using multicriteria decision-making methods. Journal of Construction Engineering and Management, 138(6), 751-758. https://doi.org/10.1061/(ASCE)CO.1943-7862.0000488

Sarkis, J., Meade, L. M., \& Presley, A. R. (2012). Incorporating sustainability into contractor evaluation and team formation in the built environment. Journal of Cleaner Production, 31, 40-53. https://doi.org/10.1016/j.jclepro.2012.02.029

Saaty, T. L. (1980). The analytic hierarchy process. New York: McGraw-Hill.

Song, C. H. (2019). Deriving and assessing strategic priorities for outsourcing partner selection in pharmaceutical R\&D: an approach using Analytic Hierarchy Process (AHP) based on 34 experts' responses from Korean pharmaceutical industry. Journal of Pharmaceutical Innovation, 14, 66-75. https://doi.org/10.1007/s12247-018-9336-y

Turskis, Z. (2008). Multi-attribute contractors ranking method by applying ordering of feasible alternatives of solution in terms of prefer ability technique. Technological and Economic Development, 14(2), 224-239. https://doi.org/10.3846/1392-8619.2008.14.224-239

Ulubeyli, S., \& Kazaz, A. (2016). Fuzzy Multi-criteria decision making model for subcontractor selection in international construction projects. Technological and Economic Development of Economy, 22(2), 210-234. https://doi.org/10.3846/20294913.2014.984363

Ustinovičius, L., Shevchenko, G., Barvidas, A., Ashikhmin, I. V., \& Kochin, D. (2010). Feasibility of verbal analysis application to solving the problems of investment in construction. Automation in Construction, 19(3), 375-384. https://doi.org/10.1016/j.autcon.2009.12.004

Yang, J. B., Wang, H. H., Wang, W. C., \& Ma, S. M. (2016). Using data envelopment analysis to support best-value contractor selection. Journal of Civil Engineering and Management, 22(2), 199-209. https://doi.org/10.3846/13923730.2014.897984

Zavadskas, E. K., Kaklauskas, A., \& Vilutienė, T. (2009). Multicriteria evaluation of apartment blocks maintenance contractors: Lithuanian case study. International Journal of Strategic Property Management, 13(4), 319-338. https://doi.org/10.3846/1648-715X.2009.13.319-338 
Zavadskas, E. K., \& Vilutienè, T. (2006). A multiple criteria evaluation of multi-family apartment block's maintenance contractors: I - Model for maintenance contractor evaluation and the determination of its selection criteria. Building and Environment, 41(5), 621-632. https://doi.org/10.1016/j.buildenv.2005.02.019

Zavadskas, E. K., Turskis, Z., \& Antuchevičienè, J. (2015). Selecting a contractor by using a novel method for multiple attribute analysis: Weighted Aggregated Sum Product Assessment with Grey Values (WASPAS-G). Studies in Informatics and Control, 24(2), 141-150. https://doi.org/10.24846/v24i2y201502

Zavadskas, E. K., Turskis, Z., \& Tamošaitienė, J. (2008). Contractor selection of construction in a competitive environment. Journal of Business Economics and Management, 9(3), 181-187. https://doi.org/10.3846/1611-1699.2008.9.181-187

Zhang, J. L., Qi, X. W., \& Liang, C. Y. (2018). Tackling complexity in green contractor selection for mega infrastructure projects: a hesitant fuzzy linguistic MADM approach with considering group attitudinal character and attributes' interdependency. Complexity, Article ID 4903572, 31. https://doi.org/10.1155/2018/4903572 